\title{
Portraits of Children's Autonomy in PAUD Alam Minangkabau
}

\author{
Reni Junita Saria, ${ }^{1}$, Nurhafizah ${ }^{\text {b, }}$ Yaswindac \\ a, b, c Early Childhood Education, Faculty of Education, Universitas Negeri Padang, Indonesia \\ 1 renijunitasari20@gmail.com
}

\begin{abstract}
This article is motivated by the results of research on how children's autonomy in PAUD Alam Minangkabau. Autonomy is one aspect of human personality that cannot stand alone, this means that autonomy is related to other aspects of personality such as social aspects, emotional aspects, physical and psychological aspects. The purpose of this study is to describe how the autonomy of children in PAUD Alam Minangkabau. Data collection techniques used are the format of observation, interviews, and documentation. Observations focused on children and interviews were conducted with school principals and teachers on how to instill autonomy. From the results of this study, it is illustrated that almost all children have good autonomy where autonomy has been well developed through the collaboration of parents and teachers in the development of children's autonomy. With the existence of such cooperation the development of autonomy can be carried out maximally. Seen when the child can be left by parents at school and do various activities for him without having to be helped by teachers or other adult.
\end{abstract}

Keywords:

Portrait; Autonomy; Children of PAUD Alam Minangkabau

This is an open access article under the CC-BY-NC license.

\section{INTRODUCTION}

Education is a fundamental aspects in the continuation of human life. This requires knowledge of skills and attitudes so that humans can adapt themselves to their family environment and the community environment. Children's education at an early age has an extraordinary influence on children's development because it lays the foundation for further development. When the children grows up, education at an early age will provide a deep scar and significantly affect the attitude, behavior, and intelligence (Nurhafizah \& Azlina, 2015).

Early Childhood Education is a level of education that is generally between the ages of 4-6 years. Education in this kindergarten is not compulsory education (Masitoh; 2009), but its role is vital as a fundamental educational stage. Therefore education in kindergarten requires special attention from teachers, parents, and also from the government and managing foundations. Without attention from various parties, education in kindergarten will not achieve maximum results as expected. At present, education in kindergarten is still in a stage of change from a program that focuses on social and emotional development into kindergarten that emphasizes academic values, especially reading, writing, mathematics, and science, and preparing children to think and solve problems.

Early childhood education is education given from the children birth to eight years old. Education 
for early childhood is the basis for the formation of the human personality as a whole, which is characterized by nature, noble character, intelligence and skill. Early childhood education must be based on the needs of children, adjusted to the values held in the surrounding environment. Education provided must be following the stages of child development and carried out in a playful atmosphere (Yaswinda, Yulsyofriend, Farida Mayar, 2018).

In order for the development process to be carried out successfully according to the expected goals, the teacher can determine approaches, strategies, methods, and media that are appropriate to the development of students. Marrison (2012) states that the practice of development following development is Developmentally Appropriate Practice (DAP), which means that the teacher's teaching practice is based on the way children grow and develop. DAP is a recommended teaching practice in this profession, so it is hoped that teachers can understand how children grow and develop at all stages of development, namely cognitive, linguistic, social, emotional, and physical.

Children are scientific scientists because, through their five senses, children can observe natural phenomena that surround them. Children are ready to carry out various activities in order to understand and master their environment. These periods are critical periods in which a child needs the right stimuli to achieve perfect maturity. If at this critical time, the child can get the right stimulation in the form of exercise or learning process, the child will experience difficulties in the next developmental period. In this way, the learning process of children from an early age is vital (Nurhafizah, 2017).

One aspect of personality that must be developed in early childhood is autonomy. Autonomy in English is called autonomy, which is an attitude in the form of a decision to take a risk, manage yourself, without obtaining or asking for help from others. (Santrock 2018). In obtaining autonomy, socially, emotionally, and intellectually, children must be allowed to be responsible for what they do. Independent children are usually able to overcome problems faced in their developmental stages, such as being able to regulate themselves and not depend on others.

Self-reliance is one that must be possessed of adult life skills and is one of their developmental tasks. However, autonomy will not arise by itself without the excellent guidance and conditions of childhood (Yaswinda, 2013).

Yamin 2012 stated that "autonomy is very closely related to children as individuals who have self-concept, self-esteem, and self-regulation". Autonomy must be trained from an early age, and the development of early childhood autonomy can be described in the form of behavior and habituation of children.

Based on the analysis of the fact of the PAUD Minangkabau, I saw the initial observation that children's autonomy is indeed well developed because it is seen when the child is wearing and removing shoes, when dating or coming home from school, after went to the toilet alone without the help of the teacher, and when the child is after eating, and 
playing can tidy up its own equipment; then after using all the play equipment used, children can put it back to its original place. (Martinis \& Sanan 2012) states that autonomy consists of several aspects: 1) Intellectual, this aspect is shown by the ability to manage the various problems encountered. 2) Social, this aspect is shown by the ability to interact with other people and not depend on or wait for the actions of others.

Based on the exposure previously disclosed, researchers are interested in examining the development of children's autonomy in PAUD Alam Minangkabau.

\section{RESEARCH METHOD}

Based on the above discussion, the researcher can take the hypothesis as follows:

Ha: there is an effect of the use of educational media game tools on the creativity of children aged 4-5 years

Ho: there is no effect of the use of educational media game tools on the creativity of children aged 4-5 years

\section{THEORETICAL PERSPECTIVES}

Based on the problems and research objectives formulated by researchers, this type of research is descriptive research with a qualitative approach. Qualitative research is a research that intends to understand the phenomena about what is experienced by research subjects holistically and using descriptions in the form of words and languages, in a particular natural context, and by utilizing various scientific methods (Moleong, 2007).

Researchers in this study will observe the development of children's autonomy. Therefore the researchers chose the research subjects by saturation sampling. According to (Sugiyono 2009), saturation sampling is a technique when all members are used as samples. This is often done when the population is relatively small, less than 30 people, or research that wants to make generalizations with minimal errors.

There are 3 classes with 20 children in Early Childhood Education (PAUD) Alam Minangkabau. Therefore, researchers chose Minangkabau Nature Early Childhood Education (PAUD) as the object of research. As for what will be the subject of research are the principal as the leader and policymaker in PAUD Alam Minangkabau, as well as the teacher as an educator who provides education and learning services as well as instilling autonomy for all students.

Data collection techniques used include: (1) Observation to be disguised. Disguised observations are observations made on research informants, and research informants know that they are being studied. However, one day the researcher is also not forthright about a matter because he wants to obtain confidential data (Sugiyono, 2012). The number of objects studied was 20 people.

\section{RESULTS AND DISCUSSION}

Based on observations made on 8, 9, 10, 11, 15, 17 October 2018 in PAUD Alam Minangkabau the children here have seen their autonomy, namely 1 ) 
From the aspect of emotional autonomy in which the children here can be left by their parents at school, patiently waiting for the queue to wash their hands and turn to read the iqra, then patiently in the queue to shake hands with the teacher when they come home from school. 2) From the aspect of children's intellectual autonomy, where the child does the work from the teacher to completion, and the child can answer the questions given by the teacher. 3) From the aspect of children's social autonomy, where children want to share food and drinks with friends, and children also want to share toys with their friends.

On October 17, 2018, where an interview with the school principal was held about how the principal's collaboration with the teacher was in establishing autonomy for children. Children in PAUD Alam Minangkabau are taught about how autonomy so when the children here have been given trust, the children in each task or activity can do it themselves so that with the belief that children will be independent in addition to our collaboration with the teacher here we also do a collaboration with parents so that this autonomy children can also do at home.

Then on 11, 16, 23 October 2018 with the teacher about the autonomy of children were about the guidelines of aspects of children's autonomy. All the answers given by the teacher are almost the same as the children at school, the emotional aspects of children's autonomy can be left at school, from the aspect of intellectual autonomy of the child independently. They can do their tasks given by the teacher to completion and the last aspect of social autonomy where the children here also socially independent because children can share food or drink with friends and can also share toys with their friends.

The researcher's findings describe the research data based on observations, interviews, and documentation in viewing the description of the autonomy. This research was conducted in class B with respondents in class $B$. The informants were teachers in class $A 1, A 2$, and $B$.

1. Based on observations

a) Monday 08 October 2018

This is where the autonomy of children can be assessed when children can wash their own hands, prepare their food, and share their peers who do not bring food or drink.

\section{b) Tuesday 09 October 2018}

Where the child is introduced to papaya leaves behind the class, then the child is told to pick leaves every one child picks one leaf ... And imitates the activities, and the child also does the same thing. Here the autonomy of the children is excellent because all children can do the work until completion.

\section{c) Wednesday 10 October 2018}

Where the social aspect of the autonomy of children is seen here when the children help one another in cleaning the garden and mistaking plants.

\section{d) Thursday 11 October 2018}

Where the children here are invited by the teacher to watch together to the opposite class. Before going to the opposite class, children queued up first to line up to do watching activities. Here, the patience of the children in turns walked across to the opposite class. Then the children were enthusiastic about watching. After finished watching, the children were given more questions about what they watched earlier. 


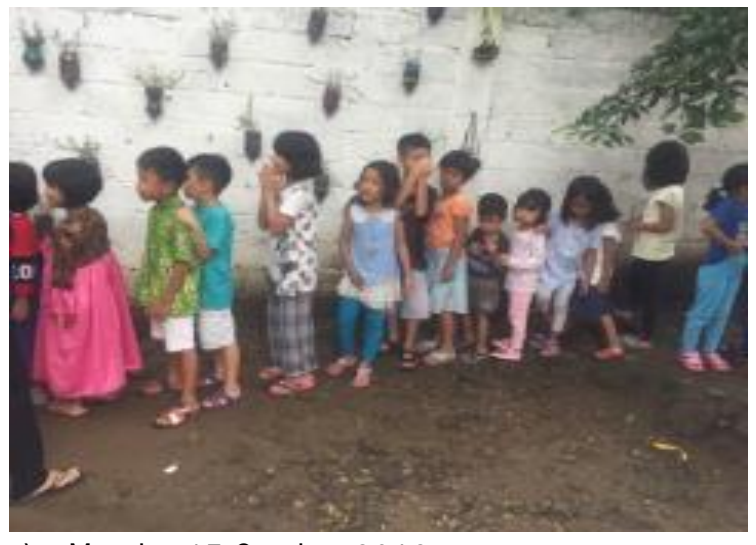

e) Monday 15 October 2018

In the child learning also shows his autonomy where the child likes to do the assignment given by the teacher and do it himself without assistance until completion.

\section{f) Wednesday, October 17, 2018}

After taking iqra, children take turns to read iqra with the teacher. That day the child's autonomy is seen when the child is patiently waiting for his turn, which aspect of the child's emotional autonomy is seen.

\section{Discussion}

Based on the results of the study, researchers will describe the discussion of data analysis, because this study is descriptive with a qualitative approach, then the data collection techniques that researchers use are guidelines for observation, interviews, and documentation. The researchers' results that have been obtained will be used to obtain the expected results. Then it will be relevant to the related discussion.

The results of researchers that researchers have gotten from the results of observations, interviews, and documentation is a descriptive study of the autonomy of children in Alam Minangkabau PAUD.
The child's autonomy will develop well if the child is given space and opportunity to do things as he wishes, act without coercion, and feel comfortable with the environment. In line with Yamin's 2013 proposal, 81 that the child will become independent once he feels comfortable with the environment

Surdana (2014: 1) states that Early Childhood Education is a coaching effort aimed at children from an early age through the provision of educational stimuli to help growth and development physically and spiritually so that children have the readiness to enter the next stage of primary education in life.

Furthermore Trianto (2011: 24) states, Early Childhood Education (PAUD) is a coaching effort that is shown to children from birth until the age of six years which is carried out through the provision of educational stimuli to help physical and spiritual growth and development so that children have readiness in entering further education.

Also, according to Susanto 2018, 94 states the term autonomy in English is called autonomy, is an attitude in the form of a decision to take a risk, manage yourself, without obtaining or asking for help from others.

Titik Kristiyani (in Syafaruddin, 2004: 147) states that autonomy can be interpreted as an ability to think, feel, and do, something itself. Autonomy can also be interpreted as a skill to help yourself both physically and psychologically. Physical autonomy is 
the ability to take care of oneself, while psychological autonomy is the ability to make decisions and solve the problems at hand.

According to Wiyana (Lina 2015: 5), there are several benefits that can be obtained if autonomy is taught from an early age, including children becoming more confident, comfortable to adjust to their environment, and not always dependent on adults (Novan Ardy Wiyani, 2013: 33).

According to Ariyanti (in sari 2008: 28), the autonomy of early childhood has several benefits, including:

1. Directing oneself and making decisions such as being able to manage the time of their own activities, have their own type of play.

2. Social emotions like children are accustomed to helping others, and are more used to respecting others, willing to play with friends.

3. Self-management like a child can control himself when a child is running in front of him with a hole so the child will spontaneously stop because there is the ability to manage themselves, not cry when left by a caregiver or parent.

4. Finding self-identity like a child is more trusting and skilled so that the child does not hesitate or be ashamed of doing all his activities.

5. Moral like children can be responsible for the decisions they make.

Havighurst (in, Martinis \& Sanan 2012: 65)

Sanan states that autonomy consists of several aspects:

Intellectual, this aspect is demonstrated by the ability to manage various problems encountered.

Social, this aspect is shown by the ability to interact with others and is not dependent or waiting for action from others.
According to Kartono (in Wiyana, 2013: 29) aspects of autonomy Including Emotions, this aspect is shown by the ability to control emotions and not replace emotional needs from parents.

Emotion, which is shown by the child's ability to control and not depend on the emotional needs of parents; 2) intellectual, which is shown by the ability of children to overcome various problems encountered; and 3) social, which is shown by the ability of children to be able to solve their own problems, without the help of others, because if the child is able to solve the problem without the help of others, of course, it will be beneficial for the child's life later.

From some of the above opinions, it can be concluded that the aspect of autonomy consists of emotional, intellectual, and social aspects where children are used to solve their own problems without parents help

\section{CONCLUSION}

Based on the results of research from the discussions that have been conducted by researchers, it can be concluded that:

Autonomy in the emotional aspects of children in this school, almost all of their children are good. However, with the encouragement and assistance provided by teachers, children can start to grow their autonomy. Activities provided by the teachers are varied depending on the interests of the child. By looking at the interests of the child, the teacher can easily give an understanding to the child so that parents can leave it. 
The autonomy of children from the intellectual aspect seen here all their children are independent and can do their own tasks to complete. The way teachers here make children can enjoy learning and completing assignments given by the teacher, which is done alone by studying outside the room so that the activities are not monotonous and boring.

The autonomy of children from the social aspects of children in this school is functional because the children here can share food with their friends, and children can also socialize with all their friends. No children are picky about friends. It because the teachers have started to embed the nature of sharing and not choosing friends from early in their school years, so that the children can develop and implement the social aspects well.

\section{REFERENCES}

George S Marrison. 2012. Pelaksanaan strategi pembelajaran scaffolding melalui permainan di TK B sebagai upaya mengangkat pemahaman konsep bilangan (artikel). 553-Yuli Haryati, Ismartoyo-2177-4480-1SM.pdf.semarang

Gaffar. 2011. Pendidikan karakter anak usia dini sebagai generasi muda untuk menggapai bonus demografi (artikel).77-5-Diana Vidya Fakhriyani-ipi498755-pdf.madura

Moleong, Lexi. 2007. Metodelogi Penelitian Kualitatif. Bandung: Remaja karya
Moleong, lexy. 2006. Metodelogi Penelitian Kualitatif. Bandung: PT. Remaja Rosdakarya

Masitoh. 2009. Pelaksanaan strategi pembelajaran scaffolding melalui permainan di TK B sebagai upaya mengangkat pemahaman konsep bilangan (jurnal).55-3-Yuli Haryati, Ismartoyo-2177-4480-1-SM.pdf.semarang

Nurhafizah \& Azlina Mohd. Kosnin. 2015. Implementasi Permainan Tradisional Indonesia Di Taman Kanak-Kanak Kota Padang. Jurnal IImiah IImu Pendidikan. Volume XV No.1 April 2015.

Nurhafizah, Nurhafizah. 2017. Strategi Pengembangan Kemampuan Sains Anak Taman Kanak-Kanak Di Koto Tangah Padang. Jurnal Anak Usia Dini dan Pendidikan Anak Usia Dini . (Volume 3 No. 3b). 103-104.

Santrock. 2007. Perkembangan anak. Jakarta: Erlangga

Susanto. 2018. Bimbingan Dan Konseling di Sekolah. Jakarta: Prenada Media Group

Sugiyono. 2012. Metode Penelitian Kuantitatif, Kualitatif, dan $R \& D$ D. Bandung: Rosdakarya

Wiyana NovanArdy.2013. Bina Karakter AUD.Yogyakart\&qAruzz Media

Yamin, Martinis dan Sanan.2012. Panduan Paud.Jakarta: Gaung Persada Press Group.

Yaswinda. Yulsyofriend, \& Farida Mayar. 2018. Pengembangan Bahan Pembelajaran Sains Berbasis Multisensori Ekologi Bagi Guru Paud Kecamatan Tilatang Kamang Kabupaten Agam. Jurnal Pendidikan Anak Usia Dini. (Volume 2 No. I), 13

Yaswinda, Yaswinda. 2018. GROWING ROLE OF TEACHERS AUTONOMY CHILDREN AGE 2-4 YEARS.jurnal pendidikan anak usia dini. (Volume 2 No. ), 58 